\title{
Síndrome de Lutembacher-Cossio
}

\author{
Germán Ramos, Luigi Gabrielli, Samuel Córdova.
}

Laboratorio de Ecocardiografía. División de Enfermedades Cardiovasculares. Pontificia Universidad Católica de Chile.

El Síndrome de Lutembacher-Cossio corresponde a la coexistencia de estenosis mitral, habitualmente de etiología reumática con un defecto del tabique interauricular, por lo general, comunicación interauricular tipo ostium secundum ${ }^{1}$. Su baja prevalencia y cuadro clínico oligosintomático hacen de su hallazgo un hecho excepcional, aunque se han descrito casos familiares ${ }^{2}$. A continuación se exponen imágenes ecocardiográficas de esta patología.

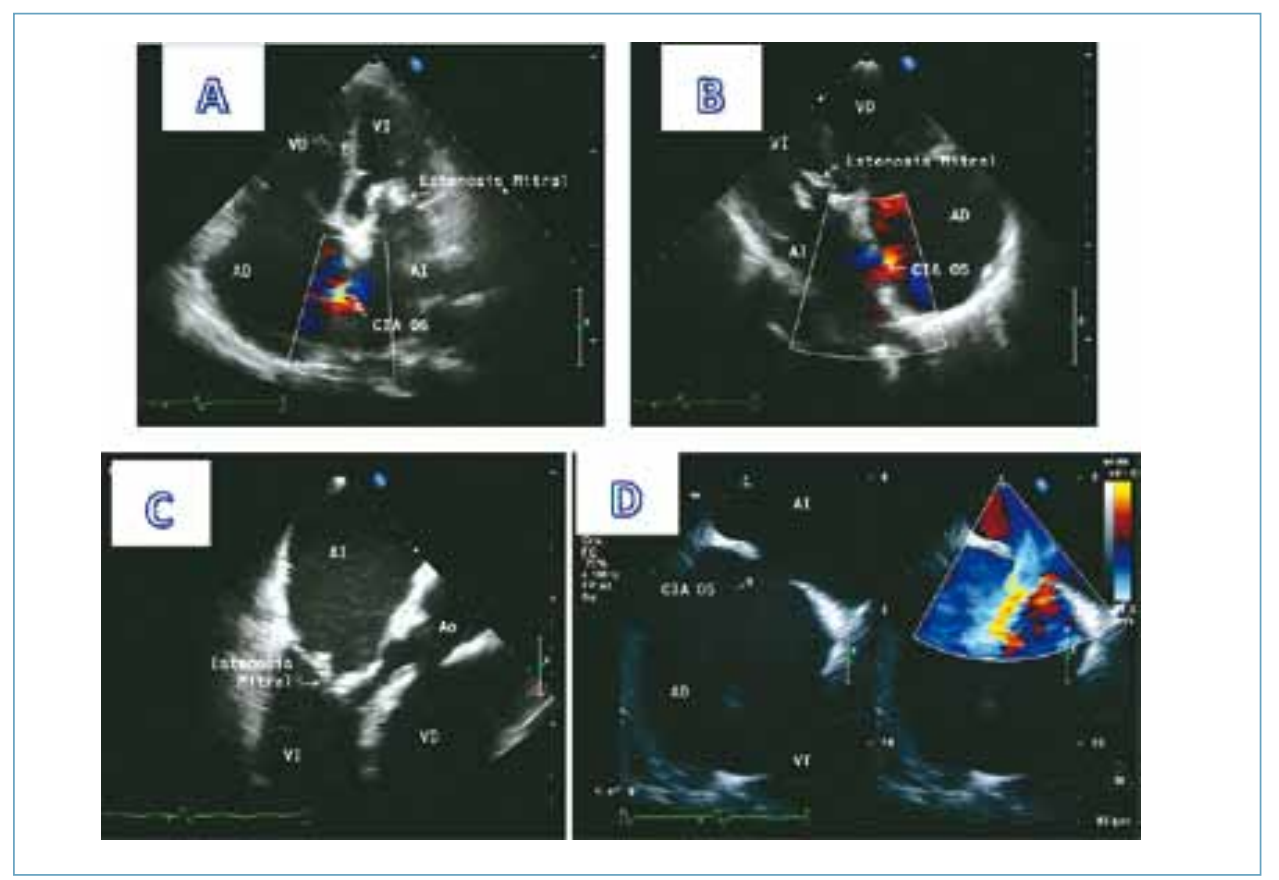

A. Ecocardiograma transtorácico, proyección apical de 4 cámaras, B. Ecocardiograma transtorácico, proyección apical 4 cámaras invertida, C. Ecocardiograma transesofágico en esófago-medio $130^{\circ}$, D. Ecocardiograma transesofágico, esófago-medio $0^{\circ}$, tabique interauricular.

Abreviaciones: AD: aurícula derecha; AI: aurícula izquierda; VD: ventrículo derecho; VI: ventrículo izquierdo; CIA OS: comunicación interauricular tipo ostium secundum; VT: válvula tricúspide; Ao: aorta.

\section{Correspondencia:}

Correspondencia: Dr. Samuel Córdova A.

Laboratorio de Ecocardiografia Hospital Clínico de la

Pontificia Universidad Católica de Chile

Correo electrónico: scordova@med.puc.cl

\section{Referencias:}

1. OLIVARES-REYES A, AL-KAMME A. Lutembacher's Syndrome with small atrial septal defect diagnosed by transthoracic and transesophageal echocardiography that underwent mitral valve replace- ment. J Am Soc Echocardiogr 2005; 18: 1105.

2. PATIL CV, VIJAYKUMAR M, PANDE AV, SHAH LS. Familial Lutembacher's syndrome in mother and daughter. Indian Heart $\mathbf{J}$ 1997; 49: 415-7. 